\title{
РАЗВОЈ И ОБЛАСТИ ПРИМЕНЕ АНАЛИЗЕ САДРЖАЈА ${ }^{1}$
}

Апстракт: Основна идеја овог рада огледа се у анализи настанка, развоја и области у којима се примењује анализа садржаја, поступак који је веома ретко коришћен у нашим истраживањима. Анализа садржаја, најједноставније речено, проучава садржај комуникације, односно учесталост и садржај порука најчешће у масовној комуникацији. У раду су анализирани различити истраживачки проблеми у којима се овај поступак примењивао, а бројна подручја примене сведоче о корисности примене овог поступка у изучавању комуникације. Указано је на разлику у обиму и областима примене међу српским истраживачима и истраживачима других.... Иако је настао у процесу истраживања политичке пропаганде за време Другог светског рата, овај поступак данас се примењује у анализи процеса комуникације у области уметности, образовања, књижевности, језика, затим, у социологији као поступак за анализу података прикупљених квалитативним методама, у истраживањима медија и слично. У раду је дат крактак преглед области и различитих истраживачких питања одређеног броја студија, не би ли се подстакли наши истраживачи за чешћу примену овог поступка који даје немерљиве резултате у проучавању процеса комуникације.

Кључне речи: анализа садржаја, области примене, политичка пропаганда, метод, медији

\section{УВОД}

Иако се почеци примене анализе садржаја, поступка који најједноставније речено, проучава учесталост и садржај порука у масовној комуникацији, везују за 30-те године 20. века, право место међу социолошким методима анализа садржаја проналази након убрзаног развоја информацијског друштва, односно масовних медија. Применом поступка анализе садржаја у проучавању садржаја комуникације могуће је открити скривене намере пошиљалаца, као и последице које они желе да произведу. Зато је важно открити „чије поруке, чије знање се простире комуникацијским каналима и ко поседује и контролише те канале“ (Гредељ, 1986:6).

Stojsin.Snezana@gmail.com 
Дуго година анализа садржаја примењивана је само у сврху истраживања политичке пропаганде, а тај период за време и након Другог светског рата допринео је учесталој примени овог метода у практичне сврхе. Након тога, анализа садржаја почиње да се примењује у различитим областима, међутим, треба напоменути да у примени овог метода код нас и у земљама у којима су друштвене науке на много вишем ступњу развоја, постоји велика разлика у примени о чему ће бити речи у наредним редовима.

\section{ИСТОРИЈА ПРИМЕНЕ АНАЛИЗЕ САДРЖАЈА}

Може се рећи да прво истраживање „квантитативне анализе садржаја штампаног материјала срећемо у 18. веку у Шведској, где је анализирано 90 свечаних песама непознатог аутора, под сумњом да садрже јеретичке поруке“ (Гредељ, 1986:15). Да би се одгонетнуло да ли поменуте песме поткопавају оданост цркви, 90 песама анализирано је тако што су пребројавани "религиозни симболи у овим песмама и упоређивана је њихова учестаност са учестаношћу тих симбола у прихваћеним збиркама из религиозних секти које су већ биле екскомунициране" (Фајгељ, 2007:381). Стојак (1990), пак, наводи да је ово истраживање о којем постоји веома мало података урађено око 1640. године, а садржало је прилично једноставне класификације "повољно-неповољно", а “ова “примена" анализе садржаја, сматра се, била је покушај шведског племства и свештенства да докаже присуство богохулних мисли" (Стојак, 1990:3).

И у наредном периоду анализа садржаја нашла је примену у анализи литературе „где су се анализирале разне стилистичке одлике енглеске поезије и прозе (нпр. дужина реченице, употреба придева, свеза итд.)“ (Берелсон, 1995:467).

Први покушај прихватања анализе садржаја као социолошког истраживачког поступка приписан је Максу Веберу. Он је 1910. године на Првом немачком дану социолога предожио “да се „шкарама и компасом“ разреже садржај новина како би се анализирале квалитативне промјене садржаја током хисторије“ (Стојак, 1990). Показујући како је протестантска етика утицала на развој капиталистичког духа и капиталистичких односа у западној Европи, Вебер је анализирао садржај бројних црквених приручника протестантских пастора. Основни циљ било је утврђивање колико су они у непосредном контакту са верницима преносили етичке ставове који су погодовали развоју капиталистичког духа. Вебер је поставио питање „шта је у животу верника био важећи морал, како је, дакле, gеловала верска оријентација позивне етике“ (Вебер, 2011:202). "Вебер у случају протестантизма није проучавао садржаје идејно најизграђенијих богословских дела (при истраживању привредне етике хиндуизма поступиће другачије), него она популарна, која су мање од сложених теолошких расправа скривала теоријски значајне индикаторе” 
(Илић, 2011:467). Овим предлогом обимне анализе писања штампе, Вебер није успео да заинтересује социологе за коришћење метода анализе садржаја $^{2}$. Гредељ наводи да је ово био “први покушај да се анализи садржаја обезбеди место у не пребогатом арсеналу социолошких истраживачких поступака" (Гредељ, 1986:16).

Анализа садржаја свој данашњи облик почиње да поприма тридесетих година 20. века када је забележена широка примена пре свега у анализи средстава јавног информисања. Тада су “први пут забележени основни елементи за развој инструмената анализе комуникација" (Стојак, 1990:4). Берелсон наводи да се почеци примене савремене анализе садржаја везују за истраживања у новинарству у којима су анализирани садржаји америчких новина. Посебно се истиче новинарска школа на Колумбија универзитету (Shool of Journalism, Columbia University), а као најзначајнија наводи се студија Малкома Вајлија (Malcom Willey) „Народне новине“ (Country Newspaper) у 1926. години. „Ове прве студије користиле су се готово искључиво непосредним садржајним категоријама (напр. унутрашњи догађаји, политика, рад, криминал, разводи бракова, спорт итд.)“ (Берелсон, 1995:467). "Развој анализе садржаја у основи је повезана са развојем масмедија и међународне политике, а анализа садржаја стекла је значај у првој половини двадесетог века услед драматичне експанзије средстава масовне комуникације (Mayring, 2002:114; Titscher et al. 2000:55)" (Kohlbacher, 2006:7).

Крајем 30-их година прошлог века све више пажње привлаче анализе јавног мњења, пропаганде и политичких симбола. Група научника окупљених око Харолда Ласвела (Harold Lasswell), често вођена непосредним практичним циљевима, својим испитивањима настављају „традицију проучавања ратне пропаганде у Првом светском рату која су двадесетих година била врло интензивна и донела научно занимљиве резултате“ (Милић, 1996:581).

Ласвел и његови сарадници дали су снажан подстицај за развој анализе садржаја, јер су проучавајући проблем комуникација у оквиру политичких теорија, унели „нове проблеме, нове поступке и нове категорије на том пољу. Интересовање Ласвела и других за проблеме јавног мишљења и пропаганде водио је, природно, и на терен проучавања комуникација, а тиме и на анализу садржаја“ (Берелсон, 1995:467). У анализу пропаганде у рату ови аутори кренули су са идејом да „поруке могу бити поуздан извор за предвиђање у погледу стварних ратних потеза и планова“ (Стојак, 1990:39), а посебно је анализирано „писање америчких профашистичких листова који су са симпатијом пратили њемачка освајања у почетку Другог светског рата, и идеологију нацизма““ (исто, 39). У оквиру ових анализа Ласвел $^{3}$ је испитивао „пропагандне пароле (глорификација, генерализација,

Опширније види: Вебер (2011): Протестантска етика и дух капитализма; Милић, 1996:578-579 Његов начин примене анализе садржаја у Другом светском рату користило је Министарство правде испитујући могуће субверзивне организације и њихову делатност. „У току рата на 
вербални напади, омаловажавање и сл.) уз употребу аналитичких категорија“ (Стојак, 1990:39). Ово „експериментално одељење за проучавање ратне комуникације при Конгресној библиотеци (Ласвел и сарадници) посветило је посебну пажњу стварању узорака, проблемима мерења ваљаности и поузданости категорија за класификацију садржаја“ (Гредељ, 1986:17).

Већ је речено да је на развој анализе садржаја пресудну улогу имао развој масовних комуникација, односно масовних медија. Поред штампаних медија, велику пажњу присталица анализе садржаја привукле су радио емисије, а најзначајнији допринос у проучавању радијског програма дао је Лазарсфелд и Биро за примењена социјална истраживања Колумбија универзитета (Bureau of Applied Social Research). Гредељ наводи да су појава новог медија, али и велика економска криза, утицали на проширење могућих предмета истраживања, те су у то време поред проучавања јавног мњења, теме истраживања били и “стереотипи, разматрања третмана појединих расних/националних мањина у средствима информисања, до испитивања “пристрасности” односно “објективности” средњошколских уџбеника историје” (Гредељ, 1986:16) и слично.

Најважније „практично“ подручје примене које је касније довело до развоја епистемолошких карактеристика анализе садржаја заправо је подручје проучавања нацистичке пропаганде за време Другог светског рата. Тако се на пример, „екипа са New School of Social Research, под руководством Hansa Speira, која је истраживала тоталитарне облике комуникације, придружила (се) Аналитичком одељењу Intelligence Servicea за проучавање страних радио-емисија““ (Гредељ, 1986:17). Они су на основу праћења емисија непријатељских радио станица предвиђали збивања у нацистичкој Немачкој и земљама савезницима да би проценили какав ефекат на борбени морал немачке војске вести о савезничким успесима. Међутим, ово свакодневно коришћење анализе садржаја „и напоран рад на праћењу и анализи програма није омогућавао истраживачима да детаљно методолошки образложе своје инструменте. По завршетку рата извршене су бројне упоредне анализе предвиђања, која су настала на основу анализе непријатељских емисија и заплењених немачких докумената“" (Гредељ, 1986:17).

Треба напоменути да је за време Другог светског рата анализа садржаја била тематски веома ограничена на истраживања политичке и ратне пропаганде, али је управо потреба за истраживањима политичке и ратне пропаганде подстакла је развој метода анализе садржаја. Коришћење овог метода у проучавању политичке пропаганде омогућава са једне стране „испитивање

пример, поређења домаће, наводно, фашистичке пропаганде са нацистичком пропагандом прихваћена су у доказном поступку од стране судова на расправама о субверзивној делатности. У исто време „многи сумњиви листови“ и радио станице ослобођени су сумње на темељу резултата који су добијени када су издања и радио преноси подвргнути квантитативној анализи.“" (Берелсон, 1995:483) 
неких трајнијих циљева пропаганде који су дубље повезани са основним идеолошким становиштем појединих покрета и организација, као и проучавање структуралних особина њихових пропагандних метода“"(Раденовић, 2007:453, Милић, 1996:582), а са друге, испитивање непосредних циљева пропаганде. Коришћење метода анализе садржаја у проучавању пропаганде према Раденовићу заснива се „на испитивању поменутих кључних симбола, парола и стереотипија којима се пропаганда служи у разради својих основних тема“" (С. речник, 2007:453)

Чини се да је крај Другог светског рата означио и крај једне етапе у развоју поступка анализе садржаја. Друга фаза, у којој је анализа садржаја стекла много више кредибилитета и чешће је почела да се користи, почиње од средине 1950-их година “када су истраживачи почели да се фокусирају на концепт речи, и на семантичке односе, а не само на њихово присуство" (Palmquist, 1980).

Ласвел је о развијености поступка анализе садржаја 50-их година 20. века написао да је прерано да се покушају поставити правила за употребу овог поступка зато јер је “техника (је) сувише нова искуство сувише ограничено да би било ко могао са сигурношћу рећи за које се циљеве анализа садржаја може најбоље употребити, шта треба да буду јединице, и како треба излагати њене резултате“ (Милић, 1996:591). Ласвел се надао да ће једног дана „можда постојати приручник који ће спецификовати стандаризоване типове истраживања која би с поверењем могло узети умерено стручно особље. (I de Soola Pool et al., The Prestige Press, p.36)" (Милић, 1996: 591), што се заправо и догодило 1955. године када је Committee on Linguistics and Psychology Social Science Research Council организовао научни скуп посвећен анализи садржаја ${ }^{4}$. Повод за организацију скупа било је све веће интересовање за епистемолошке проблеме примене анализе садржаја, а на конференцији су учествовали научници из области антропологије, историје, политичких наука, психологије, социологије. Утврђено је да овај поступак треба епистемолошки ојачати, а велика пажња посвећена је одређивању јединица анализе. Закључено је да се овај метод “све више примењује у различитим научним дисциплинама као што су: етнологија, историја, психијатрија, психоанализа, лингвистика, социологија, психологија, политичке науке, журналистика" (Стојак, 1990:267).

Три године касније, 1958. године, група научника основала је Stanford University Studies in International Conflict and Integration. Акценат је стављен на примену анализе садржаја у проучавању међународне политике, а испитивана је светска криза 1914. године и совјетско-кинески спор (North, Holsti, Zaninovich, Zinner, 1963; Gerbner, Holsti, Krippendorff, Paisley, Stone (eds.),

\footnotetext{
Као резултат овог скупа 1959. године настала је студија коју је уредио Pool, Ithiel de Sola Trends in Content Analysis (Papers. Urbana, IL: University of Illinois Press).
} 
1969)5 , затим кубанска криза 1962. године (Holsti, Brody, North, 1964)6. Десетак година касније одржана је велика конференција о поступку анализе садржаја коју је 1967. године организовала је Annenberg School of Communications. Веома важна тема на конференцији било је теоријско усмеравање истраживања у којима се примењује анализа садржаја, те је расправљано о проблемима записивања невербалне комуникације, о потреби за стандардизовањем система категорија и друго.

Након ове конференције се појавио се зборник The Analysis of Communication Content, који су уредили G. Gerbner, O. R. Holsti, K. Krippendorff, W. Paisley i P. Stone, „писци који ће у наредне две деценије, све до појаве књиге R. P. Webepa (Weбер, 1990), сачињавати готово целокупну листу најутицајнијих светских писац о анализи садржаја" (Илић, 2011:463).

У домаћој социолошкој литератури нема много радова о анализи садржаја. Значајни су следећи радови на тему анализе садржаја: поглавље Анализа садржаја Војин Милић у Социолошком мейоgy (1996), Марија Каљевић „Неке могућности примене анализе садржаја“, Социолоіија, бр 2 (1972). И Владимир Илић каже да «за тумачење домаћих достигнућа нема много садржинских основа, чак и ако би се у њих укључили доприноси педагогије и радови настали применом анализе садржаја у време и после грађанског рата у Југославији» (Илић, 2011:456). Поред горе наведених радова „С оне стране огледала“ Стјепана Гредеља је књига „у сваком погледу солидна, припадајући, ипак, већ историји наше социологије» (Илић, 2011:456). Гредељ ,је уткао теоријски оквир у саму основу свога истраживања писања листова Политиика и Борба о структури југословенског друштва“ (Илић, 2011:465). У оквиру научних радова треба навести и чланак Аљоше Мимице и Владимира Вулетића (1998) „Где се деде трећи класик?» Анализа цитираности Марксових, Веберових и Диркемових радова у часопису Социологија 19591996 “ у часопису Социолойја.

Што се тиче примене анализе садржаја у другим земљама, Сие (Hsiu-Fang Hsieh) и Шенон (Sarah E. Shanon) кажу да се анализа садржаја веома често користи у студијама из области здравства, и наводе да је између 1991. и 2002. године објављено више од 4000 чланака $^{7}$ (Hsieh, Shanon 2005:1277). Ове ауторке наводе да се анализа садржаја у великом броју студија користи као квалитативна истраживачка техника. Поред области здравства, у другим земљама, анализа садржаја користи се у најразличитијим областима, о чему ће бити речи у наредним редовима.

Види: North, Robert C, Holsti, Ole R, Zaninovic, M. George, Zinnes, Dina A, (1963): Content analysis: A handbook with applications for the study of international crisis, Northwestern university press.

6 Види: Holsti, Ole R, Brody, Richard A, North, Robert C, 1964. Measuring Affect and Action in International Reaction Models: Empirical Materials from the 1962 Cuban Crisis, Journal of Peace Research, Vol. 1, No. 3/4: 170-190.

7 Подаци Cumulative Index to Nursing and Allied Health Literature. 


\section{ОБЛАСТИ ПРИМЕНЕ АНАЛИЗЕ САДРЖАЈА}

Када се говори о областима примене анализе садржаја, треба истаћи да различити аутори различито групишу области у којима се примењује овај метод. На већ поменутом конгресу 1955. године систематизоване су области у којима се тада примењивала анализа садржаја, а могло би се рећи да је критеријум поделе наука чији се садржаји анализирају овом методом. Тада су наведене следеће области: историја (анализа писама војника из рата, портрети историјских личности, анализа историографских докумената), психологија (психолошка анализа докумената и догађаја, психопатологија, адаптација ученика у школи), психијатрија (испитивање изјава људи, садржаји речника менталних пацијената), литература (испитивања садржаја књига, структура тематике, лингвистичка истраживања), политика (политичка пропаганда, одјеци политичког деловања, политичке личности) (Стојак, 1990:268).

Јасно је да класификација области у којима се примењује анализа садржаја није урађена по јединственом критеријуму, јер рецимо, из „области“ литературе наведено је да се анализирају садржаји књига који могу бити и из горе наведених „области“ историје, социологије и слично. Покушај систематизације области примене овог метода налазимо код Војина Милића (1996), који поред примене анализе садржаја у истраживањима политичке пропаганде о чему је било речи, наводи и детаљно објашњава и друге области примене овог метода.

Уметност представља једну од области у којима се анализа садржаја примењује. Реч је о испитивању тематског садржаја ликовних уметности, филма, књижевности, а са овим је најтешње повезано „испитивање друштвених особина и карактерних црта главних јунака, позитивних и негативних ликова, нарочито оних који уживају ширу популарност у некој друштвеној средини“ (Милић, 1996:583).

Пример: Росандић и Видановић су 1987. године у истраживању “Прва дечија књига" анализирале књиге и сликовнице које су у периоду од 1980. до 1985 године биле објављене на српскохрватском језику, а које су биле намењене деци од 10 до 11 година. Ауторке су анализирале 214 наслова што чини $65 \%$ од основног скупа, а јединица анализе биле су теме које приче или песме садрже.

Анализа садржаја примењује се и у проучавању школских уџбеника, нарочито историјских, а „најпознатија испитивања ове врсте односе се на упоредну анализу приказивања историјских догађаја у којима су учествовале две или више земаља“" (исто, 585). Овде можемо издвојити један пример анализе уџбеника: истраживање уџбеника Социолоїија, Устиав и йрава ірађана, Филозофија, Истиорија и Геоірафија, које су урадили Зоран Аврамовић и Миља Вујачић. Аутори су истакли да је основни циљ истраживања „конструкција система категорија за анализу схватања демократије у уџбе- 
ницима“ (Аврамовић, Вујачић, 2010:452). Циљ ове анализе је да критички испита и анализира „структуру разумевања демократије у уџбеницима помоћу мреже великог броја институција, вредности, докумената и понашања чије чворне тачке чине пет поменутих области“ (исто, 452). Примена анализе садржаја треба да укаже на повезаност демократских устранова, али и „однос према другим нацијама и државама, као и тип демократије који преовлађује у уџбеницима.“ (исто, 452) Ови аутори анализом садржаја уџбеника из поменутих предмета испитивали су схватање појма демократије и појмове који кореспондирају са демократијом. У конкретним школским текстовима, аутори су указали „на она места у основној и додатној структури текста која подстичу развој демократских црта личности и да укаже на облик презентације који је садржан у тексту“ (исто, 452$)^{8}$.

Примена анализе садржаја у области језика према Милићу подразумева „a) испитивање стилистичких особина књижевних дела и б) испитивање степена разумљивости разних писмених састава“ (Милић, 1996:586).

Анализа садржаја своју примену налази и у сређивању изворних података у социолошким и другим истраживањима, добијених неким квалитативним методом за прикупљање података, најчешће научним разговором, а она је корисна „кад год се помоћу слободног разговора, или на основу неког другог квалитативног изворног материјала, желе успоставити систематски квантитативни подаци“ (исто, 587) . $^{9}$

Да би указао на „ширину поља“ које захтева анализа садржаја, Стојак наводи различите студије које су имале различите предмете истраживања. Пре свега, овај поступак се користио у анализи вредносног система ${ }^{10}$ који је „У неким текстовима и уопште писаним материјалима био веома често предмет анализе садржаја“ (Стојак, 1990:247). Затим наводи да се анализа

8 „Претходно читање је заправо упознавање са целином садржаја текста са усмеравањем пажње на “сигнале” текста (наслови, лекције, заступљеност ауторског суда или теоријски извори на које се позива писац уџбеника). Посматра се такође и однос основног и вантекстовног материјала, графичко-ликовна организација текста, илустрације.“ (Аврамовић, 2010:450). Следећи корак анализе садржаја усмерен је на конструкцију теоријских категорија. За израду система категорија коришћена је релевантна теоријска литература. Прво читање је сугерисало потребу “разбијања” основне категорије на уже појмовне одреднице. Наредни корак је посвећен идентификовању оног садржаја у уџбенику који је предмет истраживања. Помоћу конструисаног система категорија (области, поља, тема) посебно се обележава свака реч или синтагма, а посебно имплицитни садржај проблема који се истражује. Подаци о појављивању класификују се на посебним листама: листа наслова, листа за разумевање појма, листа о српском и страном аспекту (опште, страно, српско, југословенско), листа о српским и страним личностима, листа о документима, листа о сазнајној усмерености (чињенице, мишљења, осећања, деловање), листа о семантичкој структури (експлицитна, имплицитна, скривена, конфузна), листа о реализацији кохерентности текста, листа о дидактичко-методичком апарату (Аврамовић, 2010:451).

9 Милић наводи да овај преглед области није исцрпан, али да указује на ширину примене овог метода. Опширније о областима примене види Милић, 1996: 581-589.

10 Као пример наведена је студија коју је 1951. објавио R.K. White "Value-analysis: The Nature and Use of the Method", а позната је и његова студија у којој је методом анализе садржаја анализирао аутобиографију Ричарда Рајта „Црни дечак“. 
садржаја користила у анализи циљева и средстава ${ }^{11}$, за анализу интеракција ${ }^{12}$, анализу психолошког стања, анализу новина, испитивање мишљења и ставова и слично. Ова класификација је чини се настала на основу циљева истраживања које су аутори анализираних студија поставили.

\section{Табела 1. Број учесника у комуникацији и обласиии иримене}

\begin{tabular}{|c|c|c|c|c|}
\hline код промене & једна особа & $\begin{array}{l}\text { комуникација, } \\
\text { дијалог }\end{array}$ & група & $\begin{array}{l}\text { масовне } \\
\text { комуникације }\end{array}$ \\
\hline писмено & $\begin{array}{l}\text { агенда, } \\
\text { дневник }\end{array}$ & $\begin{array}{l}\text { писма, } \\
\text { одговори } \\
\text { на питања, } \\
\text { школски } \\
\text { радови }\end{array}$ & $\begin{array}{l}\text { белешке, } \\
\text { комуникација } \\
\text { у предузећу } \\
\text { и сл. }\end{array}$ & $\begin{array}{l}\text { новине, } \\
\text { књиге, огласи, } \\
\text { плакати, } \\
\text { публикације, } \\
\text { литература, }\end{array}$ \\
\hline усмено & $\begin{array}{l}\text { контактни код } \\
\text { менталних } \\
\text { болести, } \\
\text { објашњење } \\
\text { појмова }\end{array}$ & $\begin{array}{l}\text { разговор и } \\
\text { конверзација } \\
\text { свих врста }\end{array}$ & $\begin{array}{l}\text { дискусије } \\
\text { расправе, } \\
\text { групна } \\
\text { конверзација } \\
\text { свих врста }\end{array}$ & $\begin{array}{l}\text { експозе, } \\
\text { говори, радио } \\
\text { и тв, биоскоп }\end{array}$ \\
\hline коначни облици & $\begin{array}{l}\text { шарање, } \\
\text { аутоматизам }\end{array}$ & $\begin{array}{l}\text { одговори на } \\
\text { пројективне } \\
\text { тестове, } \\
\text { комун. са } \\
\text { другим } \\
\text { сликама }\end{array}$ & $\begin{array}{l}\text { све иконичке } \\
\text { комуникације } \\
\text { у малој групи, } \\
\text { симболи }\end{array}$ & $\begin{array}{l}\text { саобраћајни } \\
\text { знаци, } \\
\text { сликарство, } \\
\text { огласи }\end{array}$ \\
\hline $\begin{array}{l}\text { други кодови } \\
\text { нелингвистички: } \\
\text { музика, кодови } \\
\text { за друга чула, } \\
\text { простор, } \\
\text { временски } \\
\text { сигнали и сл. }\end{array}$ & $\begin{array}{l}\text { хистеричне } \\
\text { манифестације } \\
\text { код акутних } \\
\text { болести, } \\
\text { ставови, } \\
\text { гестове, тикови } \\
\text { и сл. }\end{array}$ & \multicolumn{2}{|c|}{$\begin{array}{l}\text { невербална комуникација } \\
\text { са другима: односи у } \\
\text { простору, сигнали, емотивне } \\
\text { манифестације , уобичајени } \\
\text { сигнали }\end{array}$} & $\begin{array}{l}\text { физичка } \\
\text { околина и } \\
\text { симболи, } \\
\text { градска } \\
\text { сигнализација, } \\
\text { споменици, } \\
\text { митови, } \\
\text { стереотипи... }\end{array}$ \\
\hline
\end{tabular}

Извор: Стојак, 1994:514.

Стојак наводи да могућности примене анализе садржаја зависе од броја учесника у комуникацији, а која се односе на „подручја која су једним дијелом изван класичног поимања методе, а првенствено се под тим класичним

\footnotetext{
11 Пример студије Ларсона, Греја и Фортиса у којој су ови аутори истраживали циљеве и могуће успехе које имају телевизијски програми код ученика. Опширније види Стојак, 1990:255-256.

12 Овде спада примена анализе садржаја у психијатријским истраживањима, а као пример наведена је студија неколико психијатара који су истраживали интеракцију у изражавању пацијената у терапеутским сеансама. Опширније види Стојак, 1990:256-258.
} 
приступом мисли на манифестне облике писаних комуникација и то са нагласком на квантификацију“ (Стојак, 1994:514). Поред масовних комуникација може се проучавати и комуникација са мањим бројем учесника. Различит број учесника у процесу комуникације (табела 1) отвара нова бројна подручја примене.

Стемлер наводи да је анализа садржаја веома корисна у утврђивању идентитета анонимних аутора одређених дела (која се изводи, између осталог и анализом учесталости коришћених именица, затим утврђивања функција речи); затим у испитивању трендова и образаца у одређеним документима; затим анализа садржаја пружа емпиријски основ за праћење промена у ставовима јавног мњења (Стемлер, 2001).

Аутор једне од најпширнијих класификација области примене анализе саджаја јесте Берелсон (Bernard Berelson) који је 1952. године објавио прву књигу о анализи садржаја (Content Analysis in Communication Research). Берелсон је утврдио 17 типова (области) примене анализе садржаја, а њену употребу објашњава „према важнијим главама које се узастопно обрађују на: карактеристике садржаја комуникације, узроке садржаја и последице садржаја.“ (1995:468)

У карактеристике садржаја комуникације према овом аутору спадају: опис трендова у садржају комуникације, могућност да се утврде развојне тенденције садржаја као показатеља развоја научног интересовања, затим откривање међународних разлика у садржају комуникације, поређење средстава и „нивоа“ комуникације, проверавање садржаја комуникације с обзиром на циљ, употреба анализе садржаја на конструисање и примењивање мерила на оцену комуникације, затим њено коришћење као једног степена у низу операција истраживања.

Што се тиче облика садржаја, односно његових обележја, Берелсон каже да се анализа садржаја често поистовећује са анализом пропаганде, затим се користи за мерење читљивости, за откривање стилских одлика, у анализи језика и књижевности, у беседништву и говорништву. Код објашњења произвођача садржаја овај аутор наводи да се анализа садржаја користи да би се откриле намере и друга обележја комуникатора, да би се одредило психолошко стање лица и група, затим, да би се открило постојање пропаганде, првенствено у службене сврхе.

У последњу „групу“ која се односи на учинке садржаја Берелсон наводи да се анализа садржаја користи за проналажење центра пажње прималаца поруке, за опис утицаја комуникације на ставове и владање, за испитивање ставова, вредности и интереса неког народа (откривање духа времена). Овај аутор је истакао да је ово чисто набрајање низа употребе анализе садржаја, а не класификација што треба узети у обзир ${ }^{13}$.

13 Опширније о наведеним областима примене анализе садржаја види Берелсон, 1995: 468-490 
Фајгељ је области примене анализе садржаја посматрао кроз циљеве примене и каже да се овај поступак може користити за “а) испитивање садржаја комуникације у односу на циљеве; б) идентификација намера и осталих својстава комуникатора; ц) откривања фокуса појединчеве, групне, институционалне или друштвене пажње; д) опис трендова у садржају комуникација; е) састављање и примена стандарда за комуникацију; ф) испитивање ставова, интересовања и вредности делова популације и г) кодирање одговора на питање у анкетама" (Фајгељ, 2007:382).

Раније је речено да се анализа садржаја у нашој науци скоро и не примењеује. Потпуно другачија слика је код истраживача „из иностранства“. Анализа садржаја се примењује у најразличитијим областима, о чему сведоче бројни научни чланци. У наредној табели су издвојене неке методолошке карактеристике истраживања у којима је коришћена анализа садржаја, што сведочи колико је често коришћена ова метода од стране научника из различитих области. Овде треба напоменути да су анализирани текстови узети насумично, и да више представљају илустрацију честог коришћења овог метода у најразличитијим областима, него детаљан преглед.

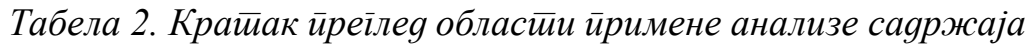

\begin{tabular}{|l|l|}
\hline наслов & предмет и циљ истраживања \\
\hline Duriau, J. Vincent; Reger, K. & Анализиран је садржај литературе \\
Rhonda; Pfarrer, D.Michael (2007). & која је на организационим студијама \\
A Content Analysis of the Content & коришћена у протеклих 25 година, \\
Analysis Literature in Organization & односно које теме су коришћене, како \\
Studies Research Themes, Data & су представљене која истраживања \\
Sources, and Methodological & менашмента су рађена и сл. \\
Refinements, Organizational Research & Истраживани су главни научни и \\
Methods, Volume 10 Number 1, & практични часописи у Еьsсо бази \\
January 2007 5-34 & података а као критеријум за одабир \\
& текстова коришћена је кључна реч \\
& анализа садржаја. \\
\hline Sjøvaag, Helle and Stavelin, & Анализа садржаја онлајн вести НБЦ \\
Eirik (2012). Web media and & (ошеgіап Вгоадсаsting Согрогаtion) \\
the quantitative content analysis: & 2009. године, а коришћен је \\
Methodological challenges in & компјутерски метод кодирања 74.430 \\
measuring online news content, & вести овог јавног сервиса. Циљ је био \\
International Journal of Research into & да се утврди како презентују вести, \\
New Media Technologies 18(2) 215- & географска и тематска покривеност, \\
229 & приоритет прве стране и слично. \\
\hline
\end{tabular}




Pedersen, Paul Mark (2002). Examing
Equity in Newspaper Photographs:
A Content Analysis of the Print
Media Photographic Coverage of
Interscholastic Athletics, International
Review for the sociology of sport, 37/
$(3-4)(2002)$ 303-318

Tillery, Bernard, Chresfield, Michell (2012). Model Blacks or "Ras the Exhorter": A Quantitative Content Analysis of Black Newspapers' Coverage of the First Wave of AfroCaribbean Immigration to the United States, Journal of Black Studies, 43(5) 545-570

Shorideh, Foroozan Atashzadeh et all (2012). Iranian intensive care unit nurses' moral distress: A content analysis, Nursing Ethics, 19(4) 464478
Анализирана је покривеност фотографијама атлетичара “средњошколаца”. Анализирано је 828 фотографија из 602 случајно одабрана текста објављених у једним новинама на Флориди током једне године. Показано је да постоји маскулинизација спорта.

Анализиран је садржај 4 новине које су од 1919. до 1940. кружиле у црначкој заједници. Циљ је био анализа представљања првог таласа имиграције Афро-Карибљана у САД, односно да се открије на који начин су “Западни Индијанци”, тада најбројнија имиграциона група, заступљени у новинама.

Анализа садржаја примењена је у анализи стреса и психолошких проблема који се јављају код медицинских сестара које раде на интензивној нези. Примењен је квалитативни метод полустуктурисаног дубинског интервјуа ca 31 медицинском сестром које раде у 12 градова у Ирану, а код којих је идентификован овај проблем. Коришћен је намерни узорак.

Анализа садржаја часописа Criminal Justice Policy Review од 1986. до 2008. године. Истраживано је ауторство, теме чланака, методи истраживања.

Анализиран је садржај реклама о дијетама, односно разликама у дијетама које се препоручују у САД и Кореји. Анализирано је по два часописа у овим земљама који су одабрани због исте циљне групе и сличног садржаја. У 2001. години одабрани су бројеви изашли током два месеца. 


\begin{tabular}{|c|c|}
\hline $\begin{array}{l}\text { Chia-Chen Yu (2009). A Content } \\
\text { Analysis of News Coverage of } \\
\text { Asian Female Olympic Athletes, } \\
\text { International Review for The } \\
\text { Sociology of Sport, 44/2-3, 283-305 }\end{array}$ & $\begin{array}{l}\text { Основни циљ је да се види колико } \\
\text { су присутни стереотипи о женама } \\
\text { спортисткињама, односно колико је } \\
\text { и даље заступљена маскулинизација } \\
\text { спорта. Анализирано је } 266 \text { новинских } \\
\text { чланака о азијским олимпијкама од } \\
\text { јануара 2000. до } 31 . \text { августа } 2008 . \\
\text { године. }\end{array}$ \\
\hline $\begin{array}{l}\text { Southern, Stephen (2006). Themes } \\
\text { in Marriage and Family Counseling: } \\
\text { A Content Analysis of The Family } \\
\text { Journal, The Family Journal: } \\
\text { Counseling and Therapy for Couples } \\
\text { and Families, Vol. } 14 \text { No. 2, 114-122 }\end{array}$ & $\begin{array}{l}\text { Анализом садржаја разматране су } \\
\text { најфреквентније теме у брачном } \\
\text { и породичном саветовалишту у } \\
\text { Породичном журналу. Испитивани су } \\
\text { сви бројеви Журнала од јануара } 1993 . \\
\text { до октобра 2005. године, са циљем да се } \\
\text { испитају промене у овом 13.огодишњем } \\
\text { периоду. }\end{array}$ \\
\hline $\begin{array}{l}\text { Illman, Deborah; Clark, Fiona (2003). } \\
\text { Content Analysis of New York Times } \\
\text { Coverage of Space Issues for the Year } \\
2000 \text {, Science Communication, Vol. } 25 \\
\text { No. 1,14-38 }\end{array}$ & $\begin{array}{l}\text { Анализиран је садржај текстова у } \\
\text { којима се налазе подаци или нека прича } \\
\text { о свемиру. Анализирани су текстови } \\
\text { који су током 2000. године објављени } \\
\text { у Њујорк Тајмсу, а основни циљ је био } \\
\text { да се утврди како медији покривају ово } \\
\text { питање уз претпоставку да се све више } \\
\text { пише о томе. }\end{array}$ \\
\hline $\begin{array}{l}\text { Dresler-Hawkea, Emma et all, (2009). } \\
\text { What are New Zealand children } \\
\text { eating at school? A content analysis of } \\
\text { 'consumed versus unconsumed' food } \\
\text { groups in a lunchbox survey, Health } \\
\text { Education Journal 68(1), 3-13 }\end{array}$ & $\begin{array}{l}\text { Студија се базира на подацима } \\
\text { прикупљеним у основној школи о } \\
\text { понашању деце у одабиру хране. } \\
\text { Подаци су прикупљени анкетирањем и } \\
\text { анализом садржаја. Анализирано је и } \\
927 \text { дечијих кутија за ручак. }\end{array}$ \\
\hline $\begin{array}{l}\text { Nikolaev, Alexander (2009). Imaes of } \\
\text { War: Content Analysis of the Photo } \\
\text { Coverage of the War in Kosovo, } \\
\text { Critical Sociology, 35(1), 105-130, }\end{array}$ & $\begin{array}{l}\text { Анализиране су фотографије које су за } \\
\text { време рата на Косову објављене у три } \\
\text { водећа америчка часописа Newsweek, } \\
\text { Time, US News World Report. Основно } \\
\text { истраивачко питање било је: да ли } \\
\text { амерички медији ратну причу причају } \\
\text { коректно, а основна претпоставка је да } \\
\text { су фотографије објављиване на штету } \\
\text { Срба. Анализирани су бројеви изашли } \\
\text { од 01. фебруара до јуна 1999. године. }\end{array}$ \\
\hline
\end{tabular}




\begin{tabular}{|c|c|}
\hline $\begin{array}{l}\text { Nimbark, A; Davis, C (1990). Politics } \\
\text { and press: A content analysis of health } \\
\text { news in South Africa, International } \\
\text { Communication Gazette, vol 46, no. 1, } \\
1-16\end{array}$ & $\begin{array}{l}\text { Анализа садржаја двају јужноафричких } \\
\text { новина, Star i Sowetan у периоду од } \\
26.11 .1985 . \text { до 31.03.1987. године. Тада } \\
\text { је опозиција интензивно протестовала } \\
\text { против апартхејда, а била је присутна } \\
\text { велика репресија власти. Циљ је био да } \\
\text { се укаже на процес друштвених промена } \\
\text { у Јужној Африци преко анализе вести из } \\
\text { области здравства. }\end{array}$ \\
\hline $\begin{array}{l}\text { Esser, Frank; D`Angelo, Paul (2003). } \\
\text { Framing the Press and the Publicity } \\
\text { Process, American Behavioral } \\
\text { Scientist, Vol. 46, No. } 5 \text { 617-641 }\end{array}$ & $\begin{array}{l}\text { Анализа садржаја } 284 \text { приче објављене } \\
\text { од септембра до новембра у изборној } \\
\text { кампањи } 2000 . \text { године на АБЦ и НБЦ } \\
\text { вечерњим вестима. }\end{array}$ \\
\hline $\begin{array}{l}\text { Brewster, Mary; DeLong, Philip; } \\
\text { Moloney, Joseph (2012). Sex Offender } \\
\text { Registries: A Content Analysis, } \\
\text { Criminal Justice Policu Review, } \\
\text { XX(X), 1-21 }\end{array}$ & $\begin{array}{l}\text { Анализиран је садржај } 51 \text { онлајн } \\
\text { регистра осуђених сексуалних } \\
\text { преступника у свих } 50 \text { држава у САД, } \\
\text { који је законом обавезан од } 2006 . \text { године. } \\
\text { Анализиране су разлике у садржајима } \\
\text { регистара. }\end{array}$ \\
\hline
\end{tabular}

\section{ПРИМЕНА АНАЛИЗЕ САДРЖАЈА У ИСТРАЖИВАЮИМА МЕДИЈА}

Медијски садржаји данас се чине као најпогоднији за примену анализе садржаја. Стојак наводи да су примери анализе садржаја штампаних медија чешћи него анализа садржаја осталих медија, и наводи да је од момента када штампа постаје медиј масовних комуникација анализа штампе „у масовној продукцији добила изузетан истраживачки простор: велике узорке, могућност репрезентативности и поузданости, могућност континуираног праћења извора, компарабилност тематике и јединице посматрања“, односно идеалне истраживачке услове у сваком смислу“ (Стојак, 1990:32).

Речено је да организована истраживања медија почињу двадесетих година прошлог века. Тада се сматрало да медији имају огромну моћ и „да појединци не могу да се значајније одупру убеђивачкој моћи медијских порука намењених масовној публици, које су и формулисане само са циљем масовне пропаганде“ (Матић, 2002:7). Данас се анализа садржаја често примењује у циљу откривања степена пристрасности поједних медија, што заправо одговара истраживању политичке пропаганде која се данас преко медија врши на другачији начин.

Миливојевићева (2008) је, тако, истраживањем показала да нема неутралности и да извештавање о изборима зависи од уређивачке политике. Она наводи да је извештавање у електронским медијима било крајње неутрално због строге регулативе извештавања, али да се у штампаним медијима “кроз 
позитивне контексте о изборним судионицима очитавала (се) наклоност према појединим кандидатима - јасно сврставање уз неке од њих" (Миливојевић, 2008:55). Истраживање је поред електронских медија обухватило осам дневних новина различитих профила: Данас, Полийика, Блиц, Вечерње новостии, Курир, Прес, Правgа и Газетиа. Ауторка је ове анализирала текстове у овим новинама у изборној кампањи председничких избора у Србији 2008. године, а у узорак су ушли текстови објављени пред крај другог круга избора, од 25. до 31. јануара. Категорије анализе груписане су у три групе: „о 1) квалитативним показатељима опсега извјештавања и заступљености кандидата 2) вриједносном контексту приказивања и медијским стратегијама у стварању имиџа кандидата и о 3) тематској разноврсности и начину дефинирања доминантних тема кампање.“ (Миливојевић, 2008:38) Циљеви овог истраживања били су утврђивање квалитета извештавања, поштовање правних норми и новинских стандарда, нарочито објективности, затим истраживање квалитета представљања кандидата и информација на основу којих би грађани могли донети изборну одлуку. Јединица анализе био је појединачни прилог, односно ТВ, радио или новински текст (Миливојевић, 2008).

Сличан циљ у истраживању имао је и Куртић, који је испитујући у којој мери су штампани и електронски медији у стању “без вањске присиле, осигурати правично, професионално и стручно извјештавање о изборној активности", урадио анализу садржаја три дневне новине ${ }^{14}$. Аутор је у сва три дневика уочио "пристраност високог интензитета, која се показује у оба облика: преекспонирањем фаворита и подекспонирањем или замрачивањем противника". (Куртић, 2007:143). Општи закључак је да су медији затворени у своја политичка и идеолошка усмерења.

Балабанић и Мустапић такође су применили анализу садржаја на штампане медије, анализирајући шест дневних листова ${ }^{15}$ у парламентарној изборној кампањи 2007. године у Хрватској. Ови аутори су закључили да кампања није наглашавала конкретне друштвене проблеме "а најзаступљеније су биле изјаве у којима су политичари давали само опћенита обећања" (Балабанић, 2008:647). Као и у горе наведеним примерима, током изборне кампање „уочена је изразита оријентираност дневних новина на двије водеће политичке странке и занемаривање осталих политичких странака“" (исто, 664).

На актуелност примене анализе садржаја у истраживању политичке пропаганде и медија којима се данас најчешће одашиљу пропагандни садр-

\footnotetext{
14 Узорак су чинила „три водећа босанско-херцеговачка тискана дневника“ Дневни аваз, Ослобођење и Независне новине. (опширније види Куртић, 2007)

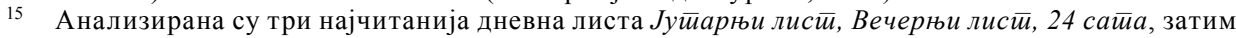
национални лист са најдужом традицијом Вјесник и два најчитанија регионална листа слобояна Далмација и Нови листи. (Балабанић, 2008:652)
} 
жаји, показује и истраживање Снежане Стојшин ${ }^{16}$ (2013) у којем је анализиран садржај новинских чланака дневних новина Блии, Вечерње новостии, Дневник, Прес и Полийика, објављених у време изборне кампање за парламентарне изборе 2008. године. Узорак је одабран из основног скупа који су чинили 4.214 текстова наведених дневних листова објављених у току изборне кампање ${ }^{17}$. Узорак је подељен на две групе, односно два подскупа. Прву групу чине 2.145 текстова који су објављени у дневним новинама од дана расписивања до дана одржавања избора. Другу групу чинило је 2.069 текстова чији је први број објављен 12. маја, дан након избора, док је последњи број са анализираним чланцима изашао 07. јула 2008. године када је формирана Влада Републике Србије.

Бројна истраживачка питања постављена у овом истраживању и одговори који су добијени применом анализе садржаја, односно резултати истраживања, указују на то шта све „може“ анализа садржаја. Акценат у истраживању стављен је на испитивање основних тема кампање, пристрасност медија, испитивање персонализације политике, и слично. Основни циљ овог истраживања био је да се открије шта је то што је на поменутим изборима према ставовима политичких партија највише привлачило пажњу бирача, односно, испитивање главних особина медијског праћења политичке комуникације, реторике у предизборној кампањи. Како се манипулација медијима најједноставније огледа у селекцији информација које се пласирају, истраживачка питања су била: колико одређени медији посвећују простора појединим партијама; затим да ли постоји селекција у информацијама која иде на штету неке партије или кандидата; даље, колики је степен зависности локалних одбора странака од њихових централа у процесу креирања политике на локалном нивоу, односно, колико су локални одбори заступљени у медијима у односу на републичке и покрајинске изборе; као и питање да ли у нашим дневним листовима пропаганда замењује информацију. Ова бројна истраживачка питања указују на веома широке могућности примене анализе садржаја на политичку пропаганду, на шта указују и резултати овог истраживања.

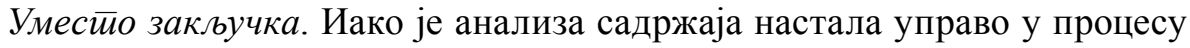
истраживања политичке пропаганде за време Другог светског рата, овај поступак данас се примењује у анализи процеса комуникације у уметности, образовању, изучавању школских уџбеника, у социологији у анализи података прикупљених квалитативним методама и слично. Посебна област истраживања, најчешће заступљена јесте област медија, у оквиру које се често срећу истраживања управо политичке пропаганде пошиљалаца пору-

16 Истраживање је део докторске дисертације „Примена анализе садржаја у истраживањима политичке пропаганде“ која је одбрањена на Филозофском факултету у Новом Саду на Одсеку за социологију 2013. године.

17 објављени од датума расписивања избора 14. марта 2008. године до дана када је формирана Влада, 7. јула те године 
ка. Анализа садржаја је од 30. година 20. века када је почела убрзано да се примењује прешла пут од искључиво практичног поступка до поступка који данас краси велики степен објективности, систематичности и прецизности. Некадашња истраживања Ласвела, Лазарсфелда и њихових садраника и данас изазивају пажњу великог броја теоретичара. Значај њихових истраживања огледа се пре свега у практичној примени овог поступка, што је касније условило и отварање питања епистемолошких проблема. Ипак, као „најважнији“ закључак претходних редова јесте тај да се анализа садржаја не примењује у оној мери у којој процес комуникације то треба, односно да га наши истраживачи заобилазе у широком луку. Са друге стране, истраживачи из других земаља поступак анализе садржаја примењују у најразличитијим приликама постављајући бројна истраживачка питања на која поступак анализе садржаја може да одговори.

\section{ЛИТЕРАТУРА:}

Аврамовић, 3. \& Вујачић, М. (2010). Однос квалитативне и квантитативне методе истраживања школских уджбеника, Теме, ХХХИВ, бр. 2, стр. 447-461.

Балабанић, И. \& Мустапић, М. (2008). Медијска реторика у предизборном раздобљу 2007, Друшиивена исираживања, год 17, бр. 4-5, стр. 647-669.

Bailey, K. D. (2007). Quantitative Methodology, in 21st century sociology: A reference handbook / coeditors in chief Clifton D. Bryant, Dennis L. Peck, London, Thousand Oaks, New Delhi: Sage Publications

Berelson, B. (1952). Content Analysis in Communication Research. New York: Free Press. Берелсон, Б. (1995). „Анализа садржаја“, у: Пејчић, Богољуб (ур.), Мейоgолойија емйиријской научної исӣраживања, Београд: Дефектолошки факултет.

Brewster, M., DeLong, P. \&Moloney, J. (2012). Sex Offender Registries: A Content Analysis, Criminal Justice Policu Review, XX(X), 1-21

Валић-Недељковић, Д. \& Пралица, Д. (2012). Коїа су меgији изабрали ... а шийа су йарӣије нуgиле?, Нови Сад: Новосадска новинарска школа.

Гредељ, С. (1986). С ону сйрану ойлеgала; Београд: Истраживачко издавачки центар ССО Србије.

Dresler-Hawkea, E. et all, (2009). What are New Zealand children eating at school? A content analysis of 'consumed versus unconsumed' food groups in a lunchbox survey, Health Education Journal 68(1), 3-13

Duriau, J. V., Reger, K. R. \& Pfarrer, D.M. (2007). A Content Analysis of the Content Analysis Literature in Organization Studies Research Themes, Data Sources, and Methodological Refinements, Organizational Research Methods,Volume 10 Number 1, January 2007 5-34

Esser, F. \& D`Angelo, P. (2003). Framing the Press and the Publicity Process, American Behavioral Scientist, Vol. 46, No. 5 617-641

Илић, В. (2011). Први александрински текст о анализи садржаја у социологији, Социолойија, вол. LIII, Но. 4, стр. 453-474

Илић, В. (2012). Други александрински текст о анализи садржаја, Социолоїија, вол. LIIV, Ho. 3. 
Illman, D. \& Clark, F. (2003). Content Analysis of New York Times Coverage of Space Issues for the Year 2000, Science Communication, Vol. 25 No. 1,14-38

Каљевић, М. (1972). Неке могућности примене анализе садржаја, Социолойија, ХИВ, број 2, стр. 215-229

Kolhbacher, F. (2006). The Use of Qualitative Content Analysis in Case Study Research, Qualitative Social Research, vol. 7, No.1, Art 21 - January 2006.

Куртић, Н. (2007). Медији и избори, Меgианали, вол. 1, број 2.

Lange, Y. (2002). Меguји и избори, Серија издања Савета Европе о медијима, број 3. Београд: Спринт

Lasswell, H. (1927). The Theory of Political Propaganda, American Political Science Review, vol 27, no. 3, aug. 1927, http://www.jstor.org/stable/10.2307/1945515

Маринковић, С. \& Пешикан, А. (1999). Типичан женски и мушки лик у уџбеницима Природе и друштва, Психолоїја, Вол. 32, Но. 3-4: 225-240

Mayring, Ph. (2000). Qualitative content analysis, Forum: Qualitative Social Research [Online Journal], 1(2), Art. 20. dostupno na: http://www.qualitative-research.net/fqs-texte/200/2-00mayring-e.htm

Minjeong, K. \& Lennon S. J. (2006). Content Analysis of Diet Advertisements: A CrossNational Comparison of Korean and U.S.Women's Magazines, International Textile \& Apparel Association, vol 24, no 4, 345-362

Миливојевић, С (2008). Промоција умјесто информације: медији и предсједнички избори у Србији 2008, Меgијска истираживања, год. 14, бр 2.

Милић, В. (1996). Социолошки меш̄оg, Београд: Завод за издавање уджбеника.

Nimbark, A. \& Davis, C. (1990). Politics and press: A content analysis of health news in South Africa, International Communication Gazette, vol 46, no. 1, 1-16

Nikolaev, A. (2009). Imaes of War: Content Analysis of the Photo Coverage of the War in Kosovo, Critical Sociology, 35(1), 105-130, http://crs.sagepub.com

Palmquist, M. (1980). Content Analysis, Research Methods in Librarianship - Techniques and Interpretaion, New York: Academic Press

Pedersen, P. M. (2002). Examing Equity in Newspaper Photographs: A Content Analysis of the Print Media Photographic Coverage of Interscholastic Athletics, International Review for the sociology of sport, 37/(3-4)(2002) 303-318

Sjøvaag, H. \& Stavelin, E. (2012). Web media and the quantitative content analysis: Methodological challenges in measuring online news content, International Journal of Research into New Media Technologies 18(2) 215-229

Southern, S. (2006). Themes in Marriage and Family Counseling: A Content Analysis of The Family Journal, The Family Journal: Counseling and Therapy for Couples and Families, Vol. 14 No. 2, 114-122

Социолошки речник (2007). Одреднице анализа садржаја (Георгиевски), ур. Аљоша Мимица и Марија Богдановић, Београд: Завод за уджбенике.

Stemler, S. (2001). An overview of content analysis. Practical Assessment, Research \& Evaluation, 7(17), November.

Стојак, Р. (1990). Метода анализе садржаја, у: Пејчић, Богољуб (ур.), Мейоgолоїија емйиријскої научної истираживања, Београд: Дефектолошки факултет.

Shorideh, F. et all (2012). Iranian intensive care unit nurses' moral distress: A content analysis, Nursing Ethics, 19(4) 464-478 
Sie, Siu-F. \& Shanon, S. E. (2005). Three Approaches to Qualitative Content Analysis, Qualitetive Health Research, November vol. 15, str. 1277-1288, http://qhr.sagepub.com/ content/15/9/1277

Стојшин, С. (2014). Квалитативна и/или квалитативна анализа садржаја - специфичности примене, Гоgишњак Филозофской факулйейа у Новом Саgу, Вол.ХХХІХ, Бр.1, стр. 193-210

Стојшин, С. (2013). Примена анализе саяржаја у исиираживањима йолиииччке йройаiaнge, Докторска дисертација одбрањена на Филозофском факултету у Новом Саду на Одсеку за социологију 2013. године.

Stinson, Ph. M. \& Huck, J. (2010). A Content Analysis of Criminal Justice Policy Review, 1986-2008, Criminal Justice Policy Review, 21(2), 239-260

Schilling, J. (2006). On the pragmatics of qualitative assessment: Designing the process for content analysis. European Journal of Psychological Assessment, 22 (1), 28-37

Tillery, B. \& Chresfield, M. (2012). Model Blacks or "Ras the Exhorter": A Quantitative Content Analysis of Black Newspapers' Coverage of the First Wave of Afro-Caribbean Immigration to the United States, Journal of Black Studies, 43(5) 545-570

Titscher, S., Meyer, M., Wodak, R., \& Vetter, E. (2000). Methods of text and discourse analysis, London: Sage.

Фајгељ, С. (2007). Мейоgе исйраживања йонашања, Београд: Центар за примењену психологију.

Chia-Chen Yu (2009). A Content Analysis of News Coverage of Asian Female Olympic Athletes, International Review for The Sociology of Sport, 44/2-3, 283-305

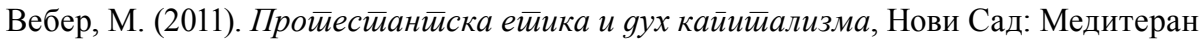




\title{
DEVELOPMENT AND FIELDS OF APPLICATION OF CONTENT ANALYSIS
}

\begin{abstract}
SUMMARY
Content analysis is, briefly speaking, a process that achieves best results in research of content of communication. The simplicity of this definition shows that this work has not dealt much with the problem of defining this procedure. Namely, the aim of this study has been achieved through analysis of the historical development of the areas in which content analysis has been applied, primarily through the analysis of opportunities to explore the political propaganda. Although content analysis has been created in the process of exploring political propaganda during the Second World War, today this process is applied in the analysis of the communication process in the arts, education, the study of school textbooks, in sociology in the analysis of data collected by qualitative methods and the like. A special area of research, which is at the same time the most common one, is the area of the media, in which research of political propaganda of message senders is fairly frequent. Through the study of mass media, by using content analysis, we have concentrated on the period when this method was practiced every day, the period when Lasswell, Lazarsfeld and their associates came to conclusions which still intrigue many theoreticians. Yet the significance of their research is primarily in the practical application of this procedure, which later caused the questions of epistemological issue. The paper points out a big difference in the frequency and application areas between our researchers and "the other ones", who apply content analysis in most varied situations.
\end{abstract}

Keywords: content analysis, application areas, political propaganda, method, media 